\title{
Combining bevacizumab and chemoradiation in rectal cancer. Translational results of the AXEBeam trial
}

M Verstraete ${ }^{1}$, A Debucquoy $^{\star}, 1$, J Dekervel ${ }^{2}, \mathrm{~J} \mathrm{van} \mathrm{Pelt}^{2}, \mathrm{C} \mathrm{Verslype}^{2}, \mathrm{E} \mathrm{Devos}^{1}, \mathrm{G}$ Chiritescu $^{3}, \mathrm{~K} \mathrm{Dumon}^{3}$, A D'Hoore ${ }^{4}$, O Gevaert ${ }^{5,6}$, X Sagaert ${ }^{7}$, E Van Cutsem $^{3}$ and K Haustermans ${ }^{1,8}$

${ }^{1}$ Laboratory of Experimental Radiotherapy, Department of Oncology, KU Leuven, Leuven, Belgium; 'Laboratory of Hepatology, Department of Clinical and Experimental Medicine, University Hospitals Leuven, KU Leuven, Leuven, Belgium; ${ }^{3}$ Department of Digestive Oncology, University Hospitals Leuven, KU Leuven, Leuven, Belgium; ${ }^{4}$ Department of Abdominal Surgery, University Hospitals Leuven, KU Leuven, Leuven, Belgium; ${ }^{5}$ Laboratory of Cancer Data Fusion, KU Leuven, Leuven, Belgium; ${ }^{6}$ Stanford Center for Biomedical Informatics Research, Stanford University, Stanford, CA, USA; ${ }^{7}$ Department of Pathology, University Hospitals Leuven, KU Leuven, Leuven, Belgium and ${ }^{8}$ Radiation Oncology, University Hospitals Leuven \& Laboratory of Experimental Radiotherapy, Leuven, Belgium

Background: This study characterises molecular effect of bevacizumab, and explores the relation of molecular and genetic markers with response to bevacizumab combined with chemoradiotherapy (CRT).

Methods: From a subset of 59 patients of 84 rectal cancer patients included in a phase II study combining bevacizumab with CRT, tumour and blood samples were collected before and during treatment, offering the possibility to evaluate changes induced by one dose of bevacizumab. We performed cDNA microarrays, stains for CD31/CD34 combined with $\alpha$-SMA and CA-IX, as well as enzyme-linked immunosorbent assay (ELISA) for circulating angiogenic proteins. Markers were related with the pathological response of patients.

Results: One dose of bevacizumab changed the expression of 14 genes and led to a significant decrease in microvessel density and in the proportion of pericyte-covered blood vessels, and a small but nonsignificant increase in hypoxia. Alterations in angiogenic processes after bevacizumab delivery were only detected in responding tumours. Lower PDGFA expression and PDGF-BB levels, less pericyte-covered blood vessels and higher CA-IX expression were found after bevacizumab treatment only in patients with pathological complete response.

Conclusions: We could not support the 'normalization hypothesis' and suggest a role for PDGFA, PDGF-BB, CA-IX and $\alpha$-SMA. Validation in larger patient groups is needed.

The standard treatment for patients with locally advanced rectal cancer (LARC) is chemoradiotherapy (CRT) followed by total mesorectal excision surgery. With this treatment still $\sim 30 \%$ of the patients will die within 5 years of completion of treatment due to the development of local and distant recurrences (Aklilu and Eng, 2011). To overcome this, an intensification of the preoperative treatment is urgently needed. One of the major factors of resistance to radiation therapy is hypoxia. Hypoxia in tumours is caused by an increase in diffusion distances with tumour expansion resulting in an inadequate supply of oxygen to cells at increasing distance from blood vessels (diffusion-related chronic hypoxia) or by chaotic vasculature and high interstitial pressures within tumours resulting in inadequate blood flow throughout the tumour (perfusion-related acute hypoxia). Anti-angiogenic treatments have been proposed to transiently normalise the tumour vasculature by pruning the immature vessels and by decreasing interstitial

*Correspondence: Dr A Debucquoy; E-mail: Annelies.debucquoy@med.kuleuven.be

Received 19 November 2014; revised 4 December 2014; accepted 12 February 2015; published online 17 March 2015

(c) 2015 Cancer Research UK. All rights reserved 0007-0920/15 
pressure, resulting in a transient increase in oxygenation and a window of opportunity for enhanced radioresponse and drug delivery (Wildiers et al, 2003; Tong et al, 2004; Winkler et al, 2004; Jain, 2005). Such combination of an anti-angiogenic agent and CRT could consequently be superior to individual treatment alone. Direct evidence was obtained in rectal cancer patients for the antivascular effect of bevacizumab (Avastin), a humanised monoclonal antibody to vascular endothelial growth factor (VEGF), which was the first angiogenesis inhibitor to be approved for cancer treatment (Willett et al, 2004).

Many phase I/II trials reported promising response rates and safety results for adding bevacizumab prior and concurrent to 5-fluorouracil (5-FU)-based CRT in the preoperative treatment of LARC (Verstraete et al, 2012). However, the pathological complete response (pCR) rate between similar studies varied between 13 and $40 \%$, stressing the importance of a good selection of patients for this combination treatment. Some trials reported pCR rates below 20\% (Czito et al, 2007; Willett et al, 2010; Kennecke et al, 2012; Dellas et al, 2013; Landry et al, 2013), which is not better than trials reported with 5-FU-based CRT alone. However, others reported higher response rates (Willett et al, 2005; Crane et al, 2010; Koukourakis et al, 2011; Nogue et al, 2011; Resch et al, 2012; Spigel et al, 2012), indicating that the addition of bevacizumab possibly offers higher efficacy to a subgroup of patients. Unfortunately, there are no prospectively validated biomarkers of response, toxicity or resistance to anti-angiogenic therapy available (Lambrechts et al, 2013). Moreover, the exact effect of bevacizumab on rectal tumours has not been fully elucidated yet. Only the group of Willett et al $(2004,2005,2009)$ analysed extensively the impact of bevacizumab monotherapy.

Accordingly, better insights in the effect of bevacizumab alone and in the molecular interaction between anti-angiogenic agents and CRT are necessary to optimise this combination treatment for LARC and to allow understanding why some subgroups respond better than others.

In our study, rectal cancer patients were treated with a combination of bevacizumab, chemotherapy (capecitabin $+1-$ oxaliplatin) and radiotherapy (AXEBeam study). The addition of oxaliplatin to fluoropyrimidine-based CRT was investigated before in several phase III trials. Apart from one report, in which the treatment schedule in the control groups might be suboptimal (Rodel et al, 2012), no improvement in pCR rate was detected when oxaliplatin was added (Gerard et al, 2010; Aschele et al, 2011; Roh et al, 2011). Therefore, we included in most of our analysis both patients that were treated with and without oxaliplatin, assuming that they would have similar treatment responses.

The main aim was to get more insight into the molecular effects of bevacizumab by studying bevacizumab-induced changes on gene expression level and different markers in blood and tissue samples in 59 included patients. In addition, we performed a subordinate exploratory analysis to identify possible key factors in the combined treatment of bevacizumab with CRT, and assessed their prognostic potential. However, the setup of this study only allows us to address relationships descriptively; no causal associations can be defined.

\section{MATERIALS AND METHODS}

Patient selection, treatment and outcome. In a Belgian investigator-driven multicentric randomised phase II study (AXEBeam, NCT00828672), 84 patients with advanced rectal cancer with bad prognostic factors ( $\mathrm{T} 2-3 \mathrm{Nx}$ with tight or threatened resection margins, T4Nx) have been treated with bevacizumab $\left(5 \mathrm{mg} \mathrm{kg}^{-1}\right)$ in combination with capecitabine $\left(1650 \mathrm{mg} \mathrm{m}^{-2}\right.$ per day) and radiotherapy ( $45 \mathrm{~Gy}, 1.8 \mathrm{~Gy}$ per day) with oxaliplatin $\left(50 \mathrm{mg} \mathrm{m}^{-2}\right.$; arm A) or without oxaliplatin (arm B; Supplementary Figure e1). The study was approved by a central Independent Ethics Committee and 59 patients gave informed consent to use samples for translational research. Table 1 lists the patient characteristics and clinical outcomes of those 59 patients. For data analysis, the pathological response was used to differentiate responders (pCR) from non-responders (no pCR). In addition, tumour regression was graded by using the Dworak regression grade.

Sample collections and storage. Tumour tissue and blood samples were collected before treatment (T0) and after the first loading dose of bevacizumab but before CRT (T1). Extra blood samples were taken after two (T2) doses of bevacizumab (during CRT). Biopsies of healthy mucosa (M) were taken at baseline (Supplementary Figure e1).

Biopsies for RNA extraction were fixed in RNA later (Qiagen $\mathrm{GmbH}$, Hilden, Germany) and stored at $-80^{\circ} \mathrm{C}$. Biopsies for tissue analysis were fixed in $4 \%$ formalin for paraffin embedding. The number of samples used for each analysis is indicated in Figure 1 with a detailed overview in Supplementary Table e1.

ELISA assays. Enzyme-linked immunosorbent assays (ELISA) to measure circulating levels of PDGF-AA, PDGF-BB, thrombospondin-1, IL-8, angiopoietin-2 and CYR61 were performed on blood samples of all 59 patients at T0, T1 and T2 (Figure 1). Quantikine R\&D System kits (R\&D Systems, Inc., Minneapolis, MN, USA) were used and the individual manufacturer's instructions of the kits were followed. The optical density was determined using the microplate reader Multiscan FC (Thermo Scientific, Waltham, MA, USA) set to $450 \mathrm{~nm}$, with a wavelength correction set to $540 \mathrm{~nm}$. Patient samples were tested in duplicate and the mean value was used for analysis. Results of all levels were expressed as $\mathrm{pg} \mathrm{ml}^{-1}$ or $\mathrm{ng} \mathrm{ml}^{-1}$ and calculated as median values \pm s.d. Extra ELISA and luminex analysis performed on a subset of the patient group can be found in Supplementary Materials and Methods.

Immunohistochemistry and scoring. The paraffin-embedded tissues of 59 patients taken at T0 and T1 were stained for haematoxylin-eosin to identify tumour. They were analysed by an

Table 1. Patient characteristics and pathological response.

\begin{tabular}{|c|c|c|}
\hline & $\begin{array}{c}\text { Arm A }(n=31), \\
\text { no. of patients (53\%) }\end{array}$ & $\begin{array}{c}\text { Arm B }(n=28), \\
\text { no. of patients (47\%) }\end{array}$ \\
\hline \multicolumn{3}{|l|}{ Age } \\
\hline $\begin{array}{l}\text { Mean } \\
\text { Range }\end{array}$ & $\begin{array}{c}59 \\
26-77\end{array}$ & $\begin{array}{c}60 \\
45-78\end{array}$ \\
\hline \multicolumn{3}{|c|}{ Gender } \\
\hline $\begin{array}{l}\text { Male } \\
\text { Female }\end{array}$ & $\begin{array}{r}9(29 \%) \\
22(71 \%)\end{array}$ & $\begin{array}{r}8(29 \%) \\
20(71 \%)\end{array}$ \\
\hline \multicolumn{3}{|c|}{ Tumour stage } \\
\hline $\begin{array}{l}\text { cT2 } \\
\text { cT3 } \\
\text { cT4 }\end{array}$ & $\begin{array}{l}2(6 \%) \\
22(71 \%) \\
7(23 \%)\end{array}$ & $\begin{array}{c}1(4 \%) \\
20(71 \%) \\
7(25 \%)\end{array}$ \\
\hline \multicolumn{3}{|c|}{ Nodal stage $^{a}$} \\
\hline $\begin{array}{l}\mathrm{cN} 0 \\
\mathrm{cN} 1 \\
\mathrm{cN} 2 \\
\mathrm{pCR}\end{array}$ & $\begin{array}{c}5 \text { (16\%) } \\
11(36 \%) \\
14(45 \%) \\
11(36 \%)^{b}\end{array}$ & $\begin{array}{c}2(7 \%) \\
9(32 \%) \\
16(57 \%) \\
3(11 \%)\end{array}$ \\
\hline \multicolumn{3}{|c|}{ Dworak } \\
\hline $\begin{array}{l}0 \\
1 \\
2 \\
3 \\
4\end{array}$ & $\begin{array}{c}1(3 \%) \\
3(10 \%) \\
4(13 \%) \\
11(36 \%) \\
11(36 \%)^{b}\end{array}$ & $\begin{array}{r}1(4 \%) \\
5(18 \%) \\
10(36 \%) \\
9(32 \%) \\
3(11 \%)\end{array}$ \\
\hline \multicolumn{3}{|c|}{ 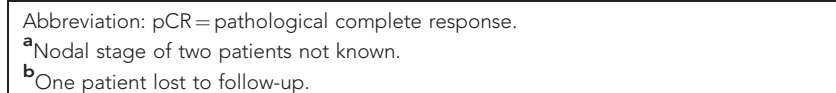 } \\
\hline
\end{tabular}




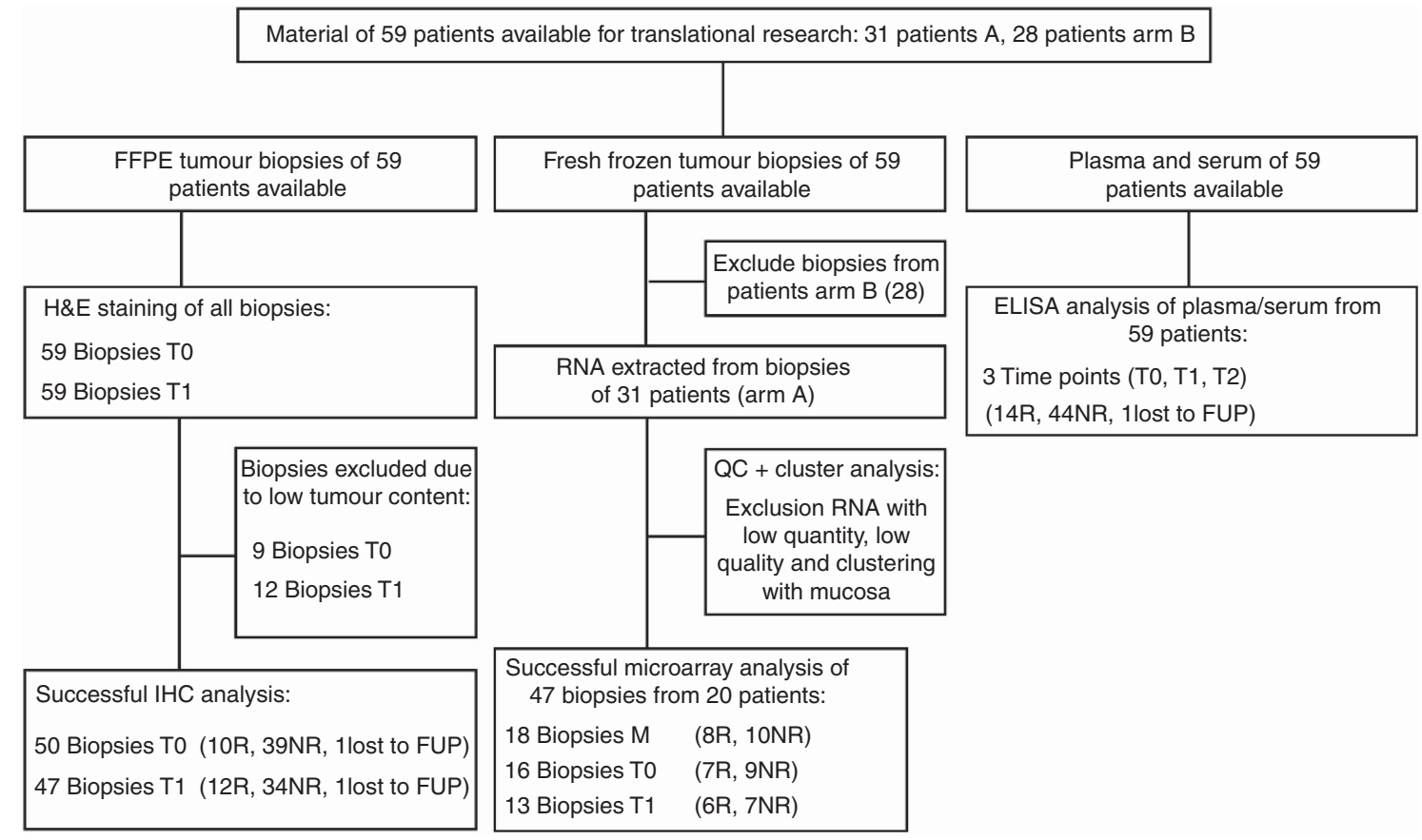

Figure 1. Inclusion and selection process of the samples used for translational research. After clinical and technical selection of the 59 patients included, 50 and 47 patients, respectively, at T0 and T1 were evaluated for tissue markers, 20 patients for gene expression levels and 59 patients for blood markers. Abbreviations: FFPE = formalin-fixed paraffin embedded; FUP = follow-up; H\&E= haematoxylin-eosin; $M=$ healthy mucosa; $N R=$ non-responder; $\mathrm{QC}=$ quality control; $\mathrm{R}=$ responder; $\mathrm{TO}=$ tumour taken at baseline; $\mathrm{T} 1=$ tumour taken after one dose bevacizumab.

experienced pathologist, and biopsies without tumour were excluded from the analysis (T0 $n=9$; T1 $n=12$ ). Immunohistochemical (IHC) analysis was performed on biopsies from 50 and 47 patients taken, respectively, at T0 and T1 (Figure 1).

Sections were stained for CD31/34 combined with $\alpha$-SMA as a measure for blood vessel maturation. CA-IX was used as marker of hypoxia. Endogenous peroxidase activity was blocked followed by antigen retrieval and a blocking step. Samples were incubated with primary antibodies and stainings were visualised using secondary antibodies followed by DAB or Vector Vip incubation. Detailed specifications on the IHC staining are listed in Supplementary Table e2.

Quantitative analysis of the immunostained histological sections for microvessel density (MVD) and CA-IX expression was performed as described earlier (Verstraete et al, 2013). CD31/34stained blood vessels surrounded by $\alpha$-SMA positivity were counted in 10 high density fields to calculate the percentage of pericyte-covered blood vessels. Several slides were reviewed by an independent observer, and no disagreement in score was found. Median values are described in the Results section.

Details about the Ki67 and cleaved PARP staining can be found in Supplementary Table e5 and Supplementary Materials and Methods.

RNA extraction and cDNA synthesis. Gene expression levels were analysed on tissue of patients from treatment arm A only in order to assess a homogenous cohort. Tissue included mucosal biopsies $(n=18)$ and tumour taken at T0 $(n=16)$, as well as T1 $(n=13$; Figure 1$)$.

Tissue was broken down by combination of physical (Dounce homogeniser) and chemical homogenisation (Trizol, Invitrogen, Life Technologies Europe B.V.) and RNA was isolated by means of RNeasy Kit (Qiagen, Chatsworth, CA, USA) according to the manufacturer's instructions. RNA quality and quantity was determined by NanoDrop spectrophotometer (NanoDrop Technologies, Centreville, DE, USA) and by means of the Agilent 2100 BioAnalyzer (Agilent, Palo Alto, CA, USA). Only RNA showing no signs of degradation or impurities (260/280 and 260/230 nm ratios, $>1.8$ ) was considered suitable for microarray analysis and used for labelling. cDNA was synthesised from $2.5 \mu \mathrm{g}$ of RNA using SuperScript II reverse transcriptase and random hexamer primers (Invitrogen, Life Technologies Europe B.V., Gent, Belgium).

Microarray and data processing. Microarray hybridisation procedure was performed on Affymetrix Primeview arrays according to the manufacturer's instructions (Affymetrix Inc., Santa Clara, CA, USA). Analysis of the microarray data was performed in the $\mathrm{R}$ programming environment in conjunction with the packages developed within the Bioconductor project (Gentleman et al, 2004). Differential expression was assessed via the moderated $t$-statistic described by Smyth (2004) and implemented in the limma package (version 3.12.1; Gentleman et al, 2004). To control the false-discovery rate, multiple testing correction was performed by the method of Benjamini and Hochberg (1995). Data are publically available through National Center for Biotechnology Information (GSE60331). Cluster analysis distinguished the tumour biopsies (T0 and T1) from the normal mucosal biopsies (M). Tumour biopsies that clustered together with the mucosal biopsies were excluded from the analysis.

Pathway analysis. Gene enrichment and pathway analysis was performed with the web-based DAVID Bioinformatics Resource 6.7 programme suite (http://david.abcc.ncifcrf.gov/) (Huang et al, 2009). Analysis was performed on the list of upregulated and downregulated genes with a fold change of $\geqslant 1$ or $\leqslant-1$ (and a corrected $P<0.001$ for the comparison between tumour and mucosa samples). The Kyoto Encyclopedia of Genes and Genomes pathways and the Gene Ontology (GO) terms of biological processes in DAVID were used to categorise enriched biological themes (significance level after Bonferonni correction $P<0.05$ ). To explore functional interactions or partnership between the genes we loaded them into the STRING 9.1 programme (http://stringdb.org/; Franceschini et al, 2013). 
Statistical analysis. The Mann-Whitney test or Kruskal-Wallis test was applied when appropriate to compare the expression of the blood and tissue markers at the different time points to evaluate the on-treatment changes. The comparison of the circulating and tissue expression levels between the responders and non-responders, as classified according to the pathological response, was done by the Mann-Whitney $U$-test and for the Dworak regression grade using the Kruskal-Wallis test. A $t$-test was used to compare treatment-induced changes (T1/T0 and T2/T0) of gene and protein expression levels between patients with and without a pCR. Median reported in Results section. A significance level of $P=0.05$ was used in all cases. Statistical analysis was done using Statistica software 12 (StatSoft Inc., Tulsa, OK, USA) and the R statistical language.

\section{RESULTS}

Impact of bevacizumab on gene expression, blood markers and tissue markers. To evaluate biomarker responses to bevacizumab treatment and to unravel its mechanism of action, we profiled gene expression changes by characterising the molecular consequences in response to one or two doses of bevacizumab. To achieve this, tumour biopsies obtained at baseline (T0) and after a single dose of bevacizumab (T1) were compared using microarray analysis and validated with ELISA and IHC at T0, T1 and T2 (Supplementary Figure e1 and Supplementary Table e1).

Changes in gene expression in response to bevacizumab. The microarray data revealed that one dose of bevacizumab changed the expression of only 14 genes in all patients (fold change of $>1$ or $<-1$; (Supplementary Table e3). Considering separate outcomes, 71 and 31 genes showed altered expression in patients with a pCR and without a pCR respectively. A functional annotation analysis of the gene changes in the responders showed significant enrichment of angiogenesis-related GO biological processes derived from nine altered genes (Table 2). No significant enriched biological processes could be found for the nonresponders.

Among those nine genes (FLT1, IL-8, PDGFA, CTGF, ROBO4, ENPEP, THBS1, ANGPT2 and CYR61), only for PDGFA, a relevant difference was found in bevacizumab-induced changes in expression between patients with and without a pCR $(P=0.1)$. As shown in Supplementary Figure e2, PDGFA expression decreased in responders with almost $10 \%$ after bevacizumab treatment (T1/ $\mathrm{T} 0=(0.8-0.9))$, whereas almost no bevacizumab-induced decrease was observed in the non-responders $(\mathrm{T} 1 / \mathrm{T} 0=(0.88-1.1))$.

Changes in circulating marker levels in response to bevacizumab. Six circulating markers (PDGF-AA, PDGF-BB, thrombospondin-1, IL-8, angiopoietin-2 and CYR61), selected based on the microarray results and literature, were quantified by ELISA. None of these markers showed significant changes in circulating levels between $\mathrm{T} 0$ and T1. However, small but significant treatmentinduced changes between T0 and T2 were observed for PDGF-AA,

Table 2. Alterations in biological processes in response to bevacizumab in responding patients

\begin{tabular}{|l|c|l|}
\hline Term & Genes & $\boldsymbol{P}$-value \\
\hline Angiogenesis & & 0.0002 \\
$\begin{array}{l}\text { Blood vessel } \\
\text { morphogenesis }\end{array}$ & FLT1, LL-8, PDGFA, CTGF, ROBO4, ENPEP, & 0.0028 \\
$\begin{array}{l}\text { Blood vessel } \\
\text { development } \\
\text { vasculature } \\
\text { development }\end{array}$ & TSP-1, ANGPT2, CYR61 & 0.0083 \\
\hline
\end{tabular}

PDGF-BB, thrombospondin-1, angiopietin-2 and IL-8. The median level and range for each biomarker at T0, T1 and T2 is shown in Supplementary Table e4.

When comparing treatment-induced changes in patients with and without a pCR, most proteins showed similar declines in both patient groups (data not shown). Only for PDGF-AA and PDGFBB, modest differences could be observed between T0 and T2. Responding patients showed a larger decrease (from 575.9 to $331.5 \mathrm{pg} \mathrm{ml}^{-1} ; P=0.11$ ) in PDGF-AA levels between T0 and T2 compared with the non-responders (from 704.1 to $539.7 \mathrm{pg} \mathrm{ml}^{-1}$; $P=0.06, P=0.06$; Figures $2 \mathrm{~A}$ and $\mathrm{B}$ ). For PDGF-BB, the treatment-induced changes were significantly larger in responding compared with non-responding patients $(P=0.002)$ with a significant decrease in responders (from 430.5 to $206.2 \mathrm{pg} \mathrm{ml}^{-1}$; $P=0.03$ ) and almost no alteration in non-responders (from 452.5 to $343.1 \mathrm{pg} \mathrm{ml}^{-1} ; P=0.18$; Figures $2 \mathrm{C}$ and $\mathrm{D}$ ). The changes of PDGF-AA and PDGF-BB on individual patient level are shown in Supplementary Figure e3.

Changes in tissue markers in response to bevacizumab. Histological data on all patients demonstrated that a single dose of bevacizumab induced a significant but small decrease in the MVD, more specifically in the proportion of vessels covered by $\alpha$-SMApositive pericytes. The MVD shifted from 74 blood vessels per $\mathrm{mm}^{2}$ (36-126 blood vessels per $\mathrm{mm}^{2}$ ) to 62 blood vessels per $\mathrm{mm}^{2}$ (22-151 blood vessels per $\left.\mathrm{mm}^{2} ; P=0.02\right)$ and the proportion of mature vessels declined from $87 \%(20-98 \%)$ before treatment to $73 \%$ (35-91\%) afterwards (T1; $P<0.0001)$. The decrease in pericyte-covered blood vessels was similar in both groups (Figures $3 \mathrm{~A}$ and $\mathrm{B}$ ). However, the effect on the MVD was more pronounced in the responders (from 71 to 53 blood vessels per $\mathrm{mm}^{2} ; P=0.11$ ) than in the non-responders (from 74 to 64 blood vessels per $\left.\mathrm{mm}^{2} ; P=0.20\right)$ although not significantly $(P=0.91$; Figures $3 \mathrm{C}$ and D).

Hypoxia, measured by CA-IX expression, showed a small but nonsignificant increase during bevacizumab treatment from 10 to $20 \%(P=0.08)$. This increase was more pronounced, although not significant $(P=0.18)$, in the responders (from 13 to $38 \%$; $P=0.15$ ) in contrast to the non-responders (from 10 to $11 \% ; P=0.41$; Figures $3 \mathrm{E}$ and $\mathrm{F}$ ). The changes in tissue markers on individual patient level are shown in Supplementary Figure e4.

Exploration of prognostic biomarkers. In order to explore prognostic biomarkers, the genes and proteins affected by bevacizumab were correlated with the pathological response of the patients and the Dworak regression grade. However, as the number of patients in some Dworak-response groups was too small (Table 1), no relevant statistical data could be obtained for this response parameter. We evaluated the expression at baseline (for selection of patients before start of treatment) and the expression after one (T1) or two (T2) loading doses of bevacizumab.

Biomarkers at baseline. When comparing gene expression between baseline tumour and mucosa samples (T0 vs M), 1585 and 1542 genes were found differentially expressed in responders and non-responders, respectively (fold change of $\geqslant 1$ or $\leqslant-1$ and $P<0.001$ ). Using these genes, 41 and $30 \mathrm{GO}$ biological processes were enriched in responders and non-responders, respectively. The unique biological processes for each patient group are presented in Table 3. Significant GO processes in the responding patients include migratory pathways such as wound healing, cell motion and motility, and pathways involved in cell proliferation such as regulation of mitosis, nuclear division and spindle organisation, which might reflect a good response to oxaliplatin. Also processes related to angiogenesis such as vasculature development, blood vessel development and blood vessel morphogenesis were enriched at baseline in responding patients but not in the non-responding patients. This could suggest 

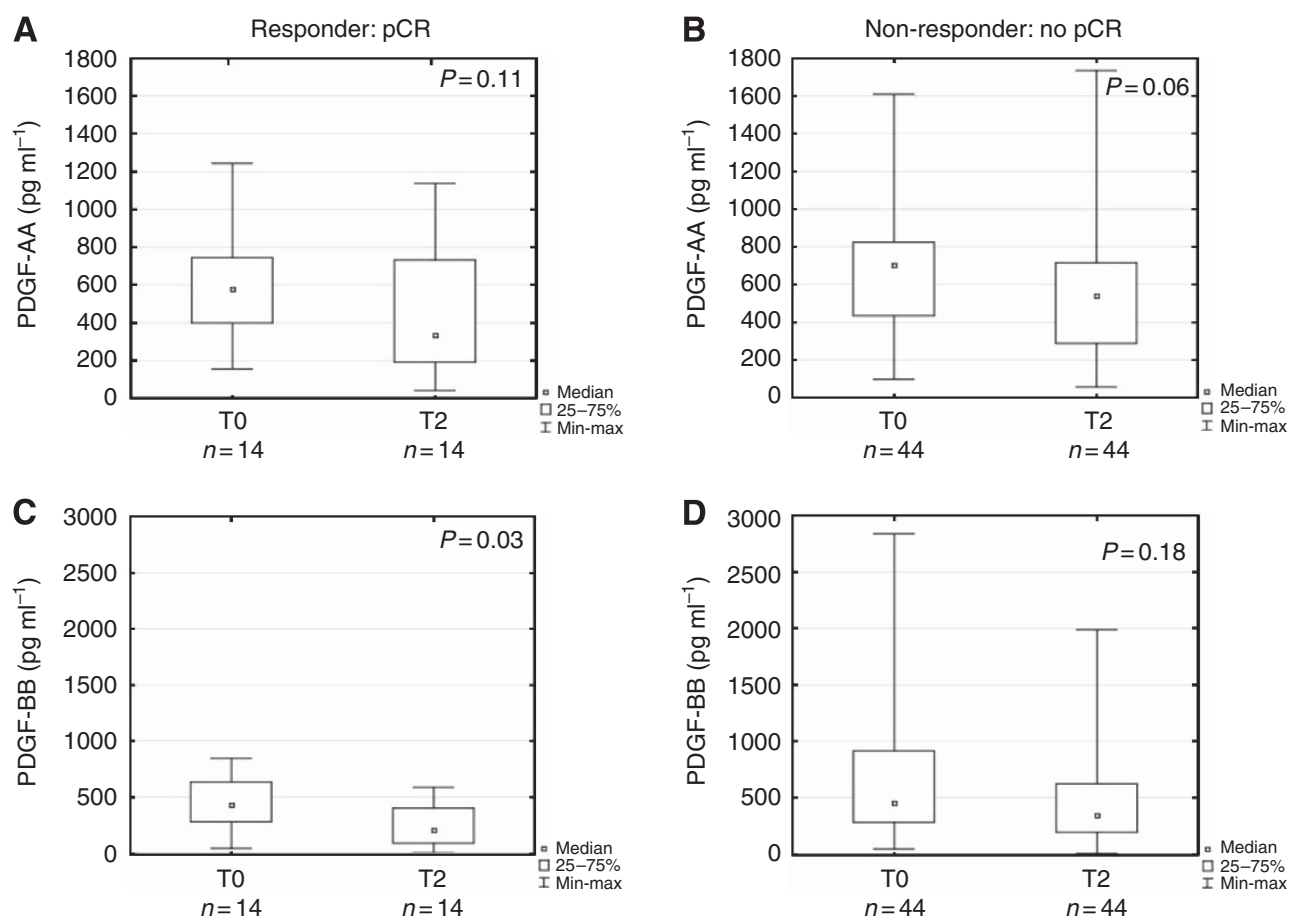

Figure 2. Changes in circulating markers during bevacizumab treatment. Box plots of circulating levels at TO and T2 measured by ELISA in responding vs non-responding patients. (A, B) Changes in PDGF-AA and (C, D) PDGF-BB levels. Each plot represents the 25th and 75th percentile. The square inside the box indicates the median, and the whiskers indicate the minimum and maximum values. $P$-values: Mann-Whitney $U$-test. Abbreviations: $\mathrm{PCR}=$ pathological complete response; $\mathrm{T} 0=$ baseline; $\mathrm{T} 2=$ after two doses bevacizumab.

that these processes show an intrinsic sensitive profile for bevacizumab treatment.

Biomarkers during bevacizumab treatment. After one loading dose of bevacizumab, patients obtaining a pCR had significant lower tumoral PDGFA expression compared with the ones without pCR (6.19 vs 6.93; $P=0.04)$, less pericyte-covered blood vessels $(64 \%$ vs $77 \% ; P=0.02)$ and a higher CA-IX expression $(38 \%$ vs $11 \% ; P=0.004$; Figures $4 \mathrm{~A}-\mathrm{C}$ ).

After two doses of bevacizumab, responders had significant lower levels of PDGF-BB $\left(206.2 \mathrm{pg} \mathrm{ml}^{-1}\right)$ compared with the nonresponders (343.1 $\mathrm{pg} \mathrm{ml}^{-1} ; P=0.04$; Figure $\left.4 \mathrm{D}\right)$.

These data indicate that PDGFA, PDGF-BB, CA-IX and pericyte-covered blood vessels might be used as prognostic markers after validation.

\section{DISCUSSION}

Investigating the effect of anti-VEGF therapy, radiotherapy and chemotherapy in clinical trials has often been hampered by the inability to perform serial tumour biopsies in patients, thereby preventing direct analysis of molecular and genetic changes after anti-angiogenic therapies. With the design of this study, we had the unique opportunity to investigate the molecular effects of a single loading dose of bevacizumab and examine potential pathways underling the interaction of VEGF inhibition and CRT.

Changes induced by bevacizumab in AXEBeam trial vs Willett et al. Until now it is still not completely clear which effect bevacizumab has on tumours from rectal cancer patients. Willett et al $(2004,2005)$ measured molecular, cellular and physiological markers before treatment and 2 weeks after one dose of bevacizumab $\left(5 \mathrm{mg} \mathrm{kg}^{-1}\right)$ on six patients from their phase I trial and on 32 patients from their phase II trial (Willett et al, 2009), in accordance with the setup of the AXEBeam trial. In Table 4, the analysed parameters are listed, and alterations observed after bevacizumab monotherapy are compared between the trials from Willett et al $(2004,2009)$ and the AXEBeam trial.

Data from Willett et al $(2004,2009)$ demonstrated antivascular and vascular normalising effects. The antivascular effects, illustrated by a decrease in blood flow, blood volume and MVD, were confirmed by our study with a decrease in MVD. The normalisation effects, which are suggested by a decrease in IFP, less angiopoitein-2-positive blood vessels, higher tumour cell proliferation and an increase in $\alpha$-SMA coverage, were not observed in the AXEBeam trial. In contrast, we observed a decrease in $\alpha$-SMA coverage, a slight increase in hypoxia and a decrease in tumour cell proliferation. Bevacizumab was found to stimulate an increase of total circulating VEGF in all studies. However, it is believed that no reliable measurement can be performed once patients have been dosed with bevacizumab, as the majority of VEGF molecules are antibody bound and thus inactive (Loupakis et al, 2007; Brostjan et al, 2008). In conclusion, the effects of bevacizumab do not seem as straightforward as presented by Willett et al $(2004,2009)$ and the normalisation hypothesis. To fully unravel the working mechanism of bevacizumab, further molecular research is needed.

Angiogenic gene profiling as biomarker. Given the low power of the study, we performed a gene group analysis that might give us more information about changes in response to treatment compared with an analysis at individual gene level. Exploring differentially expressed genes within a biological context defined by GO processes between responding and non-responding patients might give clues about relevant processes for prognosis that would be difficult to identify when evaluating differential expression of individual genes. The multiple comparison error is more pronounced for the individual gene analysis because there are much more individual genes than GO themes. Nevertheless, we have to be aware of limitations inherent to this technique (Khatri and Draghici, 2005).

Already before start of treatment, our gene expression analysis of the tumours revealed distinct intrinsic characteristics between 

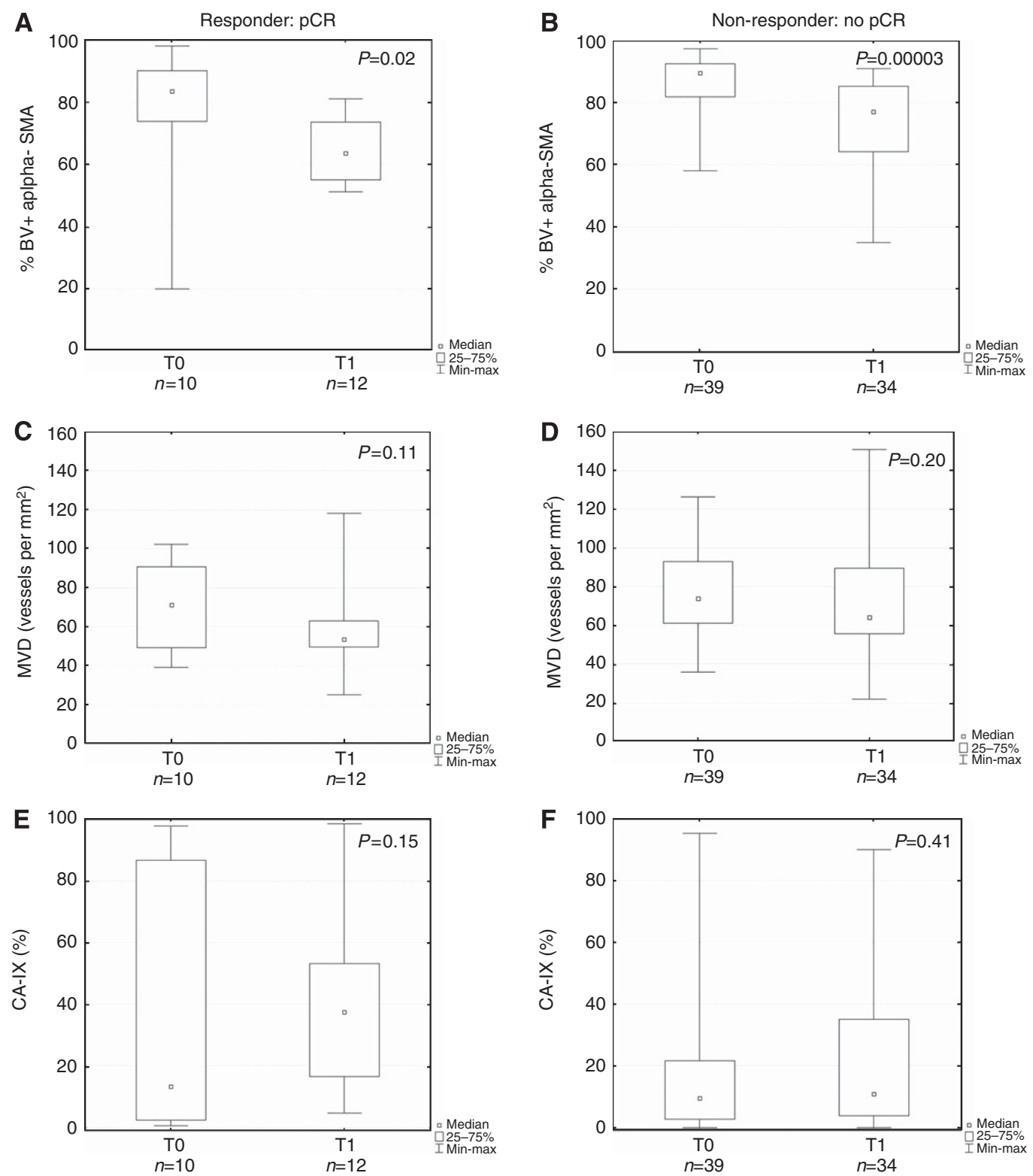

Figure 3. Changes in tissue markers during bevacizumab treatment. Box plots of expression levels at T0 and T1 measured by IHC in responding vs non-responding patients. (A, B) Changes in percentage of pericyte-covered blood vessels (BV), (C, D) MVD and (E, F) tumour hypoxia (CA-IX). Each plot represents the 25th and 75th percentile. The square inside the box indicates the median, and the whiskers indicate the minimum and maximum values. Indicated $P$-values by Mann-Whitney $U$-test. Abbreviations: $\mathrm{pCR}=$ pathological complete response; $\mathrm{T} 0=$ baseline; $\mathrm{T} 1=$ after one dose bevacizumab.

patients which after treatment showed a pCR or no pCR. First, tumours from responding patients showed to be more highly correlated to angiogenesis, hypothesising the notion that those tumours may be upfront more susceptible to anti-angiogenic treatment than tumours without an angiogenic profile. This is supported by earlier data that showed that vatalanib only has anti-angiogenic effect when the VEGFR pathway is activated (Giatromanolaki et al, 2012). Different groups have also shown that response to VEGR inhibitors can be predicted based on a set of angiogenesis-related genes (Watanabe et al, 2011; Wilson et al, 2012; Brauer et al, 2013).

Moreover, only in those responding tumours with an angiogenic phenotype, an alteration was observed after one bevacizumab dosage in angiogenesis-related GO processes, derived from nine altered genes. These angiogenic-related changes possibly indicate an effect of bevacizumab, as no biological processes were found in non-responding tumours to be influenced by one dose of bevacizumab. Consistently, Brauer et al (2013) performed microarray analysis on tumours from anti-VEGF-treated mice, revealing a decreased expression of known endothelial-specific genes and genes implicated in blood vessel development in response to antiVEGF treatment. Koukourakis et al (2009) found a direct effect of bevacizumab on specific cancer cell pathways but not on hypoxia target genes or endothelial markers.

Among all nine genes responsible for the altered angiogenic processes, only PDGFA seems to be prognostic at the individual gene level. $P D G F A$ expression decreased in response to one dose of bevacizumab in responders but not in non-responders. This makes it a possible prognostic genetic maker, with responding patients having lower PDGFA levels after one dose of bevacizumab compared with the non-responders.

Next to the aniogenic processes, gene expression analysis at baseline also revealed pathways in responder patients that might be attributed to the effect of oxaliplatin. It is know that this platinum 
compound exerts its effect through inhibition of DNA synthesis by preventing DNA replication and transcription. But it might also affect cell cycle progression (Voland et al, 2006), migration of cells

Table 3. Unique biological processes in patients with and without a pathological complete response at baseline

\begin{tabular}{|c|c|c|c|}
\hline Term & & $\begin{array}{l}\text { Gene } \\
\text { count }\end{array}$ & $P$-value \\
\hline \multicolumn{4}{|l|}{ Responders } \\
\hline GO:0001944 & Vasculature development & 61 & 0.00016 \\
\hline GO:0006928 & Cell motion & 96 & 0.00034 \\
\hline GO:0001568 & Blood vessel development & 59 & 0.00039 \\
\hline GO:0016477 & Cell migration & 63 & 0.00107 \\
\hline GO:0051325 & Interphase & 32 & 0.00353 \\
\hline GO:0006259 & DNA metabolic process & 97 & 0.00372 \\
\hline GO:0007626 & Locomotory behaviour & 61 & 0.00412 \\
\hline GO:0008285 & Negative regulation of cell proliferation & 74 & 0.00708 \\
\hline GO:0051783 & Regulation of nuclear division & 21 & 0.01059 \\
\hline GO:0007088 & Regulation of mitosis & 21 & 0.01059 \\
\hline GO:0051674 & Localisation of cell & 65 & 0.01078 \\
\hline GO:0048870 & Cell motility & 65 & 0.01078 \\
\hline GO:0048514 & Blood vessel morphogenesis & 49 & 0.01621 \\
\hline GO:0051329 & Interphase of mitotic cell cycle & 30 & 0.01822 \\
\hline GO:0007051 & Spindle organisation & 18 & 0.02463 \\
\hline GO:0042060 & Wound healing & 45 & 0.02858 \\
\hline GO:0001501 & Skeletal system development & 65 & 0.03977 \\
\hline \multicolumn{4}{|c|}{ Non-responders } \\
\hline GO:0046942 & Carboxylic acid transport & 39 & 0.00325 \\
\hline GO:0015849 & Organic acid transport & 39 & 0.00389 \\
\hline GO:0060348 & Bone development & 34 & 0.00695 \\
\hline GO:0007586 & Digestion & 28 & 0.00741 \\
\hline GO:0031667 & Response to nutrient levels & 46 & 0.01340 \\
\hline GO:0007584 & Response to nutrient & 36 & 0.01966 \\
\hline
\end{tabular}
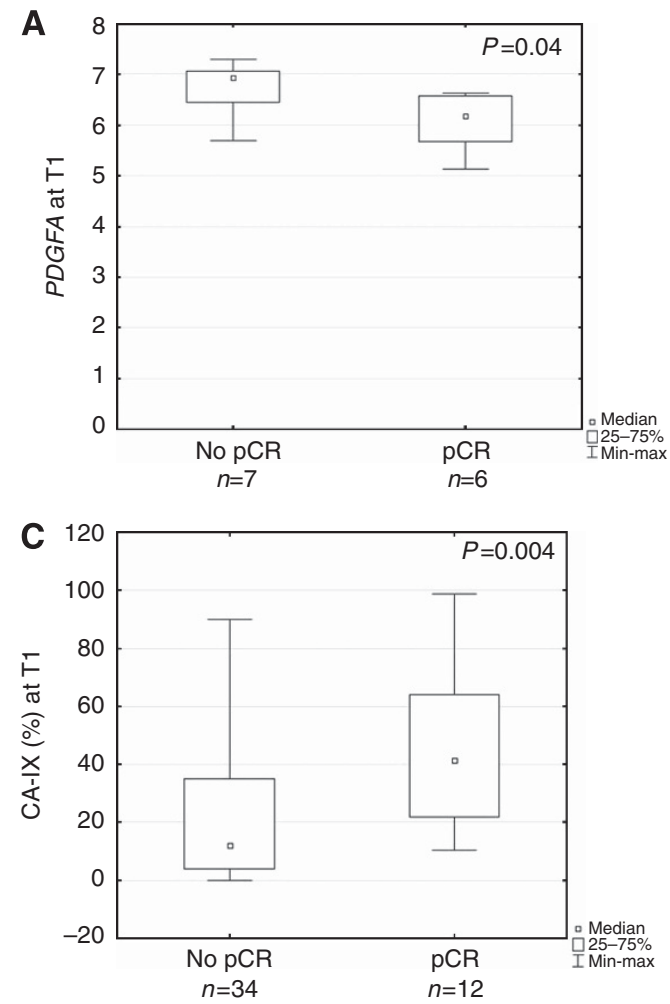

(Gaur et al, 2014) and spindle formation during mitosis (Sohn et al, 2010). As in our study, patients receiving oxaliplatin in their chemotherapy regimen ( $\operatorname{arm} \mathrm{A}$ ) show a higher $\mathrm{pCR}$ rate, those enriched biological processes in responding patients might reflect a higher sensitivity to oxaliplatin, rather than to bevacizumab. The GO category for spindle organisation was reported before to separate responders from non-responders at baseline in patients with breast cancer treated with bevacizumab and chemotherapy, but was hypothesised to be more likely relevant to the response to docetaxel (Yang et al, 2008).

Role of tissue biomarkers. Consistent with the gene expression data, bevacizumab modified certain angiogenic parameters in tumoral tissue that were more explicit in responders. Both the decrease in MVD and increase in hypoxia were more pronounced in responding patients compared with non-responders.

When looking for associations, patients with a pCR had less pericyte-covered blood vessels and more hypoxia within the tumour after one dose of bevacizumab treatment compared with patients who did not have a pCR, indicating that CA-IX and pericyte-covered blood vessels might be prognostic markers.

Apart from the decrease in MVD (Willett et al, 2004), our observations are in contrast with the literature in which according to the normalisation hypothesis (Jain, 2005), one dose of bevacizumab increased the number of pericyte-covered blood vessels (Willett et al, 2004) and decreased hypoxia (Jain, 2001; Winkler et al, 2004) leading to an enhanced radiation response and better outcome. Also, lower CA-IX expression was reported to be associated with better clinical outcome in patients treated with bevacizumab-based chemotherapy (Sathornsumetee et al, 2008; Hong et al, 2009). According to other reports pericyte content of CRC was not linked to treatment outcome in metastatic CRC patients under bevacizumab-containing therapy (Goede et al, 2010).
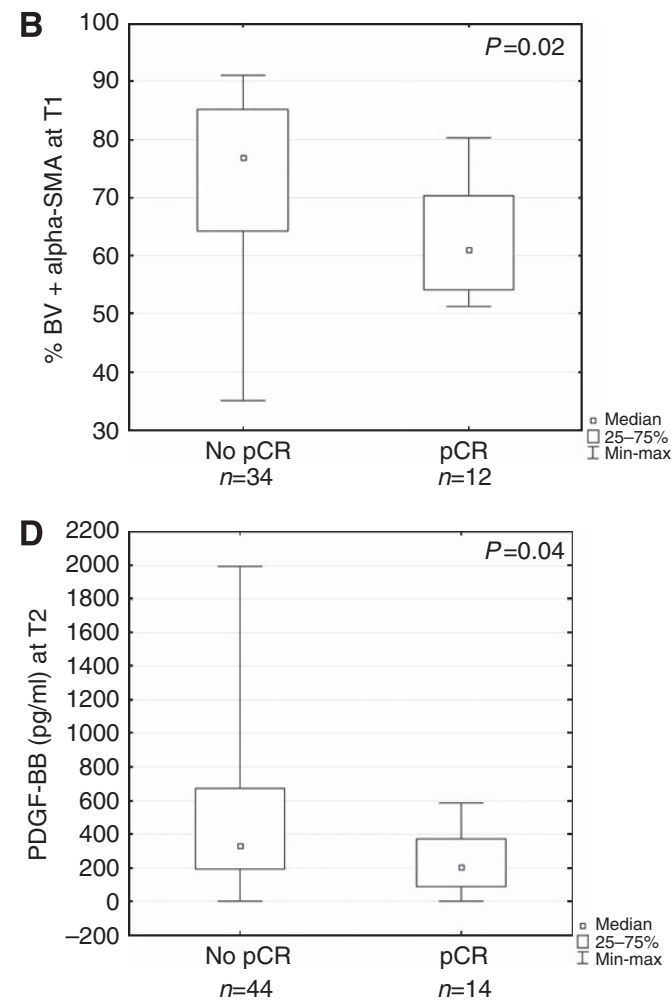

Figure 4. Correlation of markers with treatment response. Box plots of expression levels for patients with and without pCR. (A) Tumoral PDGFA expression, (B) pericyte coverage of blood vessels (BV) and (C) CA-IX expression after one dose of bevacizumab (T1). (D) Circulating PDGF-BB after two doses of bevacizumab (T2). Each plot represents the 25th and 75th percentile. The square inside the box indicates the median and the whiskers indicate the minimum and maximum values. P-values: Mann-Whitney U-test. Abbreviation: $\mathrm{pCR}=$ pathological complete response. 
Table 4. Alterations in response to one dose of bevacizumab

\begin{tabular}{|c|c|c|c|c|}
\hline Parameter & Willett phase I & Willett phase II & AXEBeam study & Willet vs AXEBeam \\
\hline Blood flow & Decrease $^{a}$ & Decrease $^{a}$ & NA & $?$ \\
\hline Blood volume & Decrease $^{a}$ & Decrease & NA & $?$ \\
\hline PS product & No effect & Decrease $^{a}$ & NA & $?$ \\
\hline FDG uptake & No effect & No effect & NA & ? \\
\hline IFP & Decrease $^{a}$ & Decrease $^{a}$ & NA & $?$ \\
\hline MVD & Decrease $^{a}$ & NA & Decrease $^{a}$ & $=$ \\
\hline$\% \alpha$-SMA coverage & Increase & NA & Decrease $^{a}$ & $\neq$ \\
\hline \% Ang-2-positive BV & Decrease $^{a}$ & NA & NA & $?$ \\
\hline Tumour cell proliferation & Increase & NA & Decrease $^{a}$ & $\neq$ \\
\hline Tumour cell apoptosis & Increase $^{a}$ & NA & No effect & $\neq$ \\
\hline CA-IX expression & NA & NA & Increase & $?$ \\
\hline CECs & Decrease $^{a}$ & No effect & NA & $?$ \\
\hline CPCs & Decrease $^{a}$ & No effect & NA & $?$ \\
\hline Circulating VEGF & Increase $^{a}$ & Increase $^{a}$ & Increase ${ }^{a, b}$ & $=$ \\
\hline Circulating PIGF & Increase $^{a}$ & $\operatorname{lncrease}^{a}$ & No effect ${ }^{c}$ & $\neq$ \\
\hline Circulating sVEGFR1 & NA & No effect & No effect ${ }^{c}$ & $=$ \\
\hline Circulating sVEGFR2 & NA & No effect & No effect ${ }^{c}$ & $=$ \\
\hline Circulating IL-6 & NA & Increase $^{a}$ & No effect ${ }^{c}$ & $\neq$ \\
\hline Circulating IL-8 & NA & No effect & Decrease & $\neq$ \\
\hline Circulating IL-1 $\beta$ & NA & No effect & NA & $?$ \\
\hline Circulating PDGF-AA & NA & NA & No effect & $?$ \\
\hline Circulating PDGF-BB & NA & NA & No effect & $?$ \\
\hline Circulating TSP-1 & NA & NA & No effect & $?$ \\
\hline Circulating TSP-2 & NA & NA & No effect ${ }^{b}$ & $?$ \\
\hline Circulating Ang-2 & NA & NA & Decrease & $?$ \\
\hline Circulating Ang-1 & NA & NA & No effect ${ }^{b}$ & $?$ \\
\hline Circulating Cyr61 & NA & NA & No effect & $?$ \\
\hline Circulating FGFa & NA & NA & No effect ${ }^{c}$ & $?$ \\
\hline Circulating FGFb & NA & No effect & No effect ${ }^{c}$ & $=$ \\
\hline Circulating osteopontin & NA & NA & No effect ${ }^{c}$ & $?$ \\
\hline Circulating sICAM & NA & NA & No effect ${ }^{c}$ & $?$ \\
\hline Circulating VEGF-D & NA & NA & No effect ${ }^{b}$ & $?$ \\
\hline Circulating SDF1 $\alpha$ & NA & No effect & NA & $?$ \\
\hline Circulating TNF- $\alpha$ & NA & No effect & NA & $?$ \\
\hline Circulating GM-CSF & NA & No effect & NA & $?$ \\
\hline Circulating CEA & NA & No effect & NA & $?$ \\
\hline Gene expression & NA & NA & cfr. Table e3 & $?$ \\
\hline Tumour regression & 1/6 Patients & No effect & NA & $?$ \\
\hline \multicolumn{5}{|c|}{ 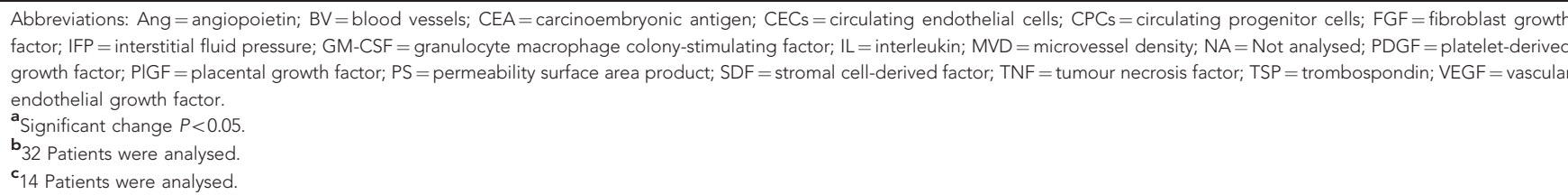 } \\
\hline
\end{tabular}

Contradicting results between our data and literature, however, could be related to small differences in the protocol and moment of sample collection, as normalisation is reported to be transient and context dependent. But then again, as VEGF facilitates the process of pericyte recruitment to endothelial cells (Benjamin et al, 1998), one could also hypothesise that blocking VEGF can result in less pericyte recruitment and coverage. When following this reasoning, the observed decrease in pericyte coverage after bevacizumab treatment in our study seems logic in contrast to the normalisation hypothesis were an increase in pericyte coverage is expected.
The complex influence of all angiogenic regulators is believed to be summarised by the MVD. Although MVD has been used before as a surrogate marker of angiogenesis in CRC and has been associated with prognosis (Frank et al, 1995; Zheng et al, 2003; Galizia et al, 2004), the significance of MVD in evaluating the response to antiangiogenic agents remains unclear. Although some reports found a positive correlation between MVD and benefit from bevacizumab plus CRT (Foernzler et al, 2010; Gasparini et al, 2012), we and others did not (Jubb et al, 2006). Nevertheless, although we could not find a correlation between MVD and response, it is remarkable that MVD 
decreased, although not significantly, after bevacizumab delivery in responding patients but not in non-responders. As mentioned before, the fraction of immature vessels provided additional information in our study, illustrating that assessing pericyte recruitment can probably more realistically indicate the angiogenic status of tumour vasculature compared with MVD counting that reflects only the presence of blood vessels.

Although we identified in responders several significant GO processes related to cell proliferation that are most likely relevant to the response to oxaliplatin, no differences were observed in Ki67 and cleaved PARP levels between responders and non-responders (data not shown).

Angiogenic circulating markers as biomarkers. Circulating PDGF-AA showed a more pronounced decrease in responders after two doses of bevacizumab (T2), which was also reflected in tumoral PDGFA expression levels. Bevacizumab treatment caused also a large decrease between T0 and T2 in circulating PDGF-BB levels in patients with a pCR, which was not observed in nonresponders. As a result, responders displayed, after two doses of bevacizumab, lower PDGF-BB levels in their blood compared with the non-responders, indicating that this protein might be used as a prognostic marker.

However, combined chemoirradiation with or without multityrosine kinase inhibitors against VEGF has also been shown to decrease circulating levels of PDGF-AA or PDGF-BB (Loven et al, 2008; Inanc et al, 2012; Shin et al, 2012). Therefore, as in our study the first cycle of CRT was already started at T2, we have to be aware that the observed decline might be partly due to the CRT.

The other four markers tested (thrombospondin-1, angiopoietin-2, IL-8 and CYR61) displayed no differences between the two response subgroups upon bevacizumab delivery, and were not found to be associated with pathological response before or after bevacizumab treatment. However, in literature, data indicate a role for some of them in response to bevacizumab (Goede et al, 2010; Huang et al, 2010; Kopetz et al, 2010; Loupakis et al, 2011; Abajo et al, 2012; Liu et al, 2013).

Hypothesis. Putting all our data together, we hypothesise that bevacizumab in this clinical trial fulfils a role as inhibitor of new blood vessel formation as it blocks VEGF as facilitator of pericyte recruitment (Benjamin et al, 1998). Our data suggest that patients respond better when the tumour has less pericyte-covered blood vessels, leading to destabilisation of the vessels that makes them more susceptible to bevacizumab, resulting in a better response. Pericytes may express VEGF as survival factor for their neighbouring endothelial cells (Darland et al, 2003; Franco et al, 2011) and provide endothelial cell survival signals. As a consequence, more mature vessels may acquire independence from tumour-secreted VEGF resulting possibly in insensitivity to VEGF withdrawal (Evensen et al, 2009; Sitohy et al, 2011), which may show resistance to bevacizumab (Helfrich et al, 2010; Sitohy et al, 2011; Weisshardt et al, 2012) and might support tumour growth. Correspondingly, more hypoxia detected in our responding patients is consistent with a less-functional vasculature and might enhance the cell kill caused by chemotherapy through hypoxia-induced apoptosis (Selvakumaran et al, 2008). Higher PDGF-BB levels in the non-responding patients are also rational as they provide mitogenic signals for pericyte recruitment and maturation (Lindahl et al, 1997; Abramsson et al, 2003), and were reported to be detected in blood of progressing patients and around vessels that developed resistance to anti-VEGF therapy (Huang et al, 2004; Kopetz et al, 2010).

This hypothesis, by which pericytes protect endothelial cells from anti-angiogenic therapy, promotes the combination of VEGF and PDGF inhibitors. Blocking the survival factor VEGF together with blockage of pericyte recruitment and maturation could prevent endothelial survival directly and indirectly (Shaheen et al, 2001; Bergers and Benjamin, 2003; Erber et al, 2004; Helfrich et al, 2010; Franco et al, 2011).

The current study should be considered as a pilot study looking for hypothesis-generating hints with several limitations. The trial did not allow us to compare results between the bevacizumab-containing regimen and CRT alone, as no arm was included without bevacizumab. Moreover, many treatments are involved in producing the observed phenotype of response, masking possible interactions and confounders. Therefore, it is impossible to speculate on a prognostic or predictive effect of the biomarkers studied, and it is not clear whether the correlations with response we observed are driven by bevacizumab, by the chemotherapy, by the radiotherapy or a combination of those treatments. One cannot exclude the possibility that the hypothesis we put forward may also be the result of mechanisms next to bevacizumab activity in this setting. Owing to a small sample size, we have to be aware of limited statistical power when interpreting our data. It should be noted that several markers identified in our study as potential biomarkers show a considerable overlap between responders and non-responders, limiting their clinical applicability. It is indeed unlikely that a single biomarker will allow differentiating between responders and non-responders. However, before any of these markers can be considered a biomarker, either on its own or in a panel of different markers, these markers should be prospectively validated in independent randomised cohorts to fully assess their prognostic or predictive value.

\section{CONCLUSION}

In summary, we could not support the 'normalization hypothesis' that states that bevacizumab results in more mature blood vessels and less hypoxia. Analysis of the microarray data showed an intrinsic angiogenic phenotype displayed in tumours from patients with a pCR. Moreover, angiogenic pathways are influenced by bevacizumab only in those tumours in contrast to non-responding tumours. Our exploratory data point towards a possible prognostic role for PDGFA, PDGF-BB, CA-IX and pericyte-covered blood vessels. Our findings suggest a role for pericyte recruitment and vessel maturation for the susceptibility of the tumour vasculature to bevacizumab treatment. Further exploration of our mechanistic hypothesis and validation of the candidate markers is demanded in large, well-powered randomised studies in order to contribute to a more rational therapeutic approach of anti-angiogenic agents in combinations with CRT.

\section{ACKNOWLEDGEMENTS}

$\mathrm{KH}$ and $\mathrm{AD}$ are supported by a fundamental clinical mandate and a post-doctoral research mandate of the FWO, respectively. JD is supported by the Flemish League against Cancer (VLK). This work was supported by Varian, and conducted with support from Roche, Sanofi Aventis and 'Vlaamse Liga tegen Kanker'.

\section{CONFLICT OF INTEREST}

The authors declare no conflict of interest.

\section{REFERENCES}

Abajo A, Boni V, Lopez I, Gonzalez-Huarriz M, Bitarte N, Rodriguez J, Zarate R, Bandres E, Garcia-Foncillas J (2012) Identification of predictive circulating biomarkers of bevacizumab-containing regimen efficacy in pre-treated metastatic colorectal cancer patients. Br J Cancer 107(2): 287-290. 
Abramsson A, Lindblom P, Betsholtz C (2003) Endothelial and nonendothelial sources of PDGF-B regulate pericyte recruitment and influence vascular pattern formation in tumors. J Clin Invest 112(8): 1142-1151.

Aklilu M, Eng C (2011) The current landscape of locally advanced rectal cancer. Nat Rev Clin Oncol 8(11): 649-659.

Aschele C, Cionini L, Lonardi S, Pinto C, Cordio S, Rosati G, Artale S, Tagliagambe A, Ambrosini G, Rosetti P, Bonetti A, Negru ME, Tronconi MC, Luppi G, Silvano G, Corsi DC, Bochicchio AM, Chiaulon G, Gallo M, Boni L (2011) Primary tumor response to preoperative chemoradiation with or without oxaliplatin in locally advanced rectal cancer: pathologic results of the STAR-01 randomized phase III trial. J Clin Oncol 29(20): 2773-2780.

Benjamin LE, Hemo I, Keshet E (1998) A plasticity window for blood vessel remodelling is defined by pericyte coverage of the preformed endothelial network and is regulated by PDGF-B and VEGF. Development 125(9): 1591-1598.

Benjamini Y, Hochberg Y (1995) Controlling the false discovery rate: a practival and powerful approach to multiple testing. J R Statist Soc Ser B 57: 289-300.

Bergers G, Benjamin LE (2003) Tumorigenesis and the angiogenic switch. Nat Rev Cancer 3(6): 401-410.

Brauer MJ, Zhuang G, Schmidt M, Yao J, Wu X, Kaminker JS, Jurinka SS, Kolumam G, Chung AS, Jubb A, Modrusan Z, Ozawa T, James CD, Phillips H, Haley B, Tam RN, Clermont AC, Cheng JH, Yang SX, Swain SM, Chen D, Scherer SJ, Koeppen H, Yeh RF, Yue P, Stephan JP, Hegde P, Ferrara N, Singh M, Bais C (2013) Identification and analysis of in vivo VEGF downstream markers link VEGF pathway activity with efficacy of anti-VEGF therapies. Clin Cancer Res 19(13): 3681-3692.

Brostjan C, Gebhardt K, Gruenberger B, Steinrueck V, Zommer H, Freudenthaler H, Roka S, Gruenberger T (2008) Neoadjuvant treatment of colorectal cancer with bevacizumab: the perioperative angiogenic balance is sensitive to systemic thrombospondin-1 levels. Clin Cancer Res 14(7): 2065-2074.

Crane CH, Eng C, Feig BW, Das P, Skibber JM, Chang GJ, Wolff RA, Krishnan S, Hamilton S, Janjan NA, Maru DM, Ellis LM, Rodriguez-Bigas MA (2010) Phase II trial of neoadjuvant bevacizumab, capecitabine, and radiotherapy for locally advanced rectal cancer. Int J Radiat Oncol Biol Phys 76(3): 824-830.

Czito BG, Bendell JC, Willett CG, Morse MA, Blobe GC, Tyler DS, Thomas J, Ludwig KA, Mantyh CR, Ashton J, Yu D, Hurwitz HI (2007) Bevacizumab, oxaliplatin, and capecitabine with radiation therapy in rectal cancer: Phase I trial results. Int J Radiat Oncol Biol Phys 68(2): 472-478.

Darland DC, Massingham LJ, Smith SR, Piek E, Saint-Geniez M, D'Amore PA (2003) Pericyte production of cell-associated VEGF is differentiationdependent and is associated with endothelial survival. Dev Biol 264(1): 275-288.

Dellas K, Hohler T, Reese T, Wurschmidt F, Engel E, Rodel C, Wagner W, Richter M, Arnold D, Dunst J (2013) Phase II trial of preoperative radiochemotherapy with concurrent bevacizumab, capecitabine and oxaliplatin in patients with locally advanced rectal cancer. Radiat Oncol 8(1): 90.

Erber R, Thurnher A, Katsen AD, Groth G, Kerger H, Hammes HP, Menger MD, Ullrich A, Vajkoczy P (2004) Combined inhibition of VEGF and PDGF signaling enforces tumor vessel regression by interfering with pericyte-mediated endothelial cell survival mechanisms. FASEB J 18(2): 338-340.

Evensen L, Micklem DR, Blois A, Berge SV, Aarsaether N, Littlewood-Evans A, Wood J, Lorens JB (2009) Mural cell associated VEGF is required for organotypic vessel formation. PLoS One 4(6): e5798.

Foernzler D, Delmar P, Kockx M, Cassidy J, Saltz L, Scherer S (2010) Tumor tissue based biomarker analysis in NO16966: a randomized phase III study of first-line bevacizumab in combination with oxaliplatin-based chemotherapy in patients with mCRC. ASCO GastroIntestinal Cancers Symposium. January 2010: abstract 374.

Franceschini A, Szklarczyk D, Frankild S, Kuhn M, Simonovic M, Roth A, Lin J, Minguez P, Bork P, von MC, Jensen LJ (2013) STRING v9.1: protein-protein interaction networks, with increased coverage and integration. Nucleic Acids Res 41(Database issue): D808-D815.

Franco M, Roswall P, Cortez E, Hanahan D, Pietras K (2011) Pericytes promote endothelial cell survival through induction of autocrine VEGF-A signaling and Bcl-w expression. Blood 118(10): 2906-2917.
Frank RE, Saclarides TJ, Leurgans S, Speziale NJ, Drab EA, Rubin DB (1995) Tumor angiogenesis as a predictor of recurrence and survival in patients with node-negative colon cancer. Ann Surg 222(6): 695-699.

Galizia G, Lieto E, Ferraraccio F, Orditura M, De VF, Castellano P, Imperatore V, Romano C, Ciardiello F, Agostini B, Pignatelli C (2004) Determination of molecular marker expression can predict clinical outcome in colon carcinomas. Clin Cancer Res 10(10): 3490-3499.

Gasparini G, Torino F, Ueno T, Cascinu S, Troiani T, Ballestrero A, Berardi R, Shishido J, Yoshizawa A, Mori Y, Nagayama S, Morosini P, Toi M (2012) A phase II study of neoadjuvant bevacizumab plus capecitabine and concomitant radiotherapy in patients with locally advanced rectal cancer. Angiogenesis 15(1): 141-150.

Gaur S, Chen L, Ann V, Lin WC, Wang Y, Chang VH, Hsu NY, Shia HS, Yen Y (2014) Dovitinib synergizes with oxaliplatin in suppressing cell proliferation and inducing apoptosis in colorectal cancer cells regardless of RAS-RAF mutation status. Mol Cancer 13: 21.

Gentleman RC, Carey VJ, Bates DM, Bolstad B, Dettling M, Dudoit S, Ellis B, Gautier L, Ge Y, Gentry J, Hornik K, Hothorn T, Huber W, Iacus S, Irizarry R, Leisch F, Li C, Maechler M, Rossini AJ, Sawitzki G, Smith C, Smyth G, Tierney L, Yang JY, Zhang J (2004) Bioconductor: open software development for computational biology and bioinformatics. Genome Biol 5(10): R80.

Gerard JP, Azria D, Gourgou-Bourgade S, Martel-Laffay I, Hennequin C, Etienne PL, Vendrely V, Francois E, de La RG, Bouche O, Mirabel X, Denis B, Mineur L, Berdah JF, Mahe MA, Becouarn Y, Dupuis O, Lledo G, Montoto-Grillot C, Conroy T (2010) Comparison of two neoadjuvant chemoradiotherapy regimens for locally advanced rectal cancer: results of the phase III trial ACCORD 12/0405-Prodige 2. J Clin Oncol 28(10): 1638-1644.

Giatromanolaki A, Koukourakis MI, Sivridis E, Gatter KC, Trarbach T, Folprecht G, Shi MM, Lebwohl D, Jalava T, Laurent D, Meinhardt G, Harris AL (2012) Vascular density analysis in colorectal cancer patients treated with vatalanib (PTK787/ZK222584) in the randomised CONFIRM trials. Br J Cancer 107(7): 1044-1050.

Goede V, Coutelle O, Neuneier J, Reinacher-Schick A, Schnell R, Koslowsky TC, Weihrauch MR, Cremer B, Kashkar H, Odenthal M, Augustin HG, Schmiegel W, Hallek M, Hacker UT (2010) Identification of serum angiopoietin-2 as a biomarker for clinical outcome of colorectal cancer patients treated with bevacizumab-containing therapy. $\mathrm{Br} J$ Cancer 103(9): 1407-1414.

Helfrich I, Scheffrahn I, Bartling S, Weis J, von Felbert V, Middleton M, Kato M, Ergun S, Augustin HG, Schadendorf D (2010) Resistance to antiangiogenic therapy is directed by vascular phenotype, vessel stabilization, and maturation in malignant melanoma. J Exp Med 207(3): 491-503.

Hong YS, Cho HJ, Kim SY, Jung KH, Park JW, Choi HS, Oh JH, Kim BC, Sohn DK, Kim DY, Chang HJ (2009) Carbonic anhydrase 9 is a predictive marker of survival benefit from lower dose of bevacizumab in patients with previously treated metastatic colorectal cancer. BMC Cancer 9: 246.

Huang D, Ding Y, Zhou M, Rini BI, Petillo D, Qian CN, Kahnoski R, Futreal PA, Furge KA, Teh BT (2010) Interleukin-8 mediates resistance to antiangiogenic agent sunitinib in renal cell carcinoma. Cancer Res 70(3): 1063-1071.

Huang dW, Sherman BT, Lempicki RA (2009) Systematic and integrative analysis of large gene lists using DAVID bioinformatics resources. Nat Protoc 4(1): 44-57.

Huang J, Soffer SZ, Kim ES, McCrudden KW, Huang J, New T, Manley CA, Middlesworth W, O’Toole K, Yamashiro DJ, Kandel JJ (2004) Vascular remodeling marks tumors that recur during chronic suppression of angiogenesis. Mol Cancer Res 2(1): 36-42.

Inanc M, Er O, Karaca H, Berk V, Ozkan M, Saraymen R, Elmali F (2012) Prognostic value of tumor growth factor levels during chemotherapy in patients with metastatic colorectal cancer. Med Oncol 29(5): 3119-3124.

Jain RK (2001) Normalizing tumor vasculature with anti-angiogenic therapy: a new paradigm for combination therapy. Nat Med 7(9): 987-989.

Jain RK (2005) Normalization of tumor vasculature: an emerging concept in antiangiogenic therapy. Science 307(5706): 58-62.

Jubb AM, Hurwitz HI, Bai W, Holmgren EB, Tobin P, Guerrero AS, Kabbinavar F, Holden SN, Novotny WF, Frantz GD, Hillan KJ, Koeppen H (2006) Impact of vascular endothelial growth factor-A expression, thrombospondin-2 expression, and microvessel density on the treatment effect of bevacizumab in metastatic colorectal cancer. $J$ Clin Oncol 24(2): 217-227. 
Kennecke H, Berry S, Wong R, Zhou C, Tankel K, Easaw J, Rao S, Post J, Hay J (2012) Pre-operative bevacizumab, capecitabine, oxaliplatin and radiation among patients with locally advanced or low rectal cancer: a phase II trial. Eur J Cancer 48(1): 37-45.

Khatri P, Draghici S (2005) Ontological analysis of gene expression data: current tools, limitations, and open problems. Bioinformatics 21(18): 3587-3595.

Kopetz S, Hoff PM, Morris JS, Wolff RA, Eng C, Glover KY, Adinin R, Overman MJ, Valero V, Wen S, Lieu C, Yan S, Tran HT, Ellis LM, Abbruzzese JL, Heymach JV (2010) Phase II trial of infusional fluorouracil, irinotecan, and bevacizumab for metastatic colorectal cancer: efficacy and circulating angiogenic biomarkers associated with therapeutic resistance. J Clin Oncol 28(3): 453-459.

Koukourakis MI, Giatromanolaki A, Sheldon H, Buffa FM, Kouklakis G, Ragoussis I, Sivridis E, Harris AL (2009) Phase I/II trial of bevacizumab and radiotherapy for locally advanced inoperable colorectal cancer: vasculature-independent radiosensitizing effect of bevacizumab. Clin Cancer Res 15(22): 7069-7076.

Koukourakis MI, Giatromanolaki A, Tsoutsou P, Lyratzopoulos N, Pitiakoudis M, Kouklakis G, Chloropoulou PA, Manolas K, Sivridis E (2011) Bevacizumab, capecitabine, amifostine, and preoperative hypofractionated accelerated radiotherapy (HypoArc) for rectal cancer: a Phase II study. Int J Radiat Oncol Biol Phys 80(2): 492-498.

Lambrechts D, Lenz HJ, de Haas S, Carmeliet P, Scherer SJ (2013) Markers of response for the antiangiogenic agent bevacizumab. J Clin Oncol 31(9): 1219-1230.

Landry JC, Feng Y, Cohen SJ, Staley III CA, Whittington R, Sigurdson ER, Nimeiri H, Verma U, Prabhu RS, Benson AB (2013) Phase 2 study of preoperative radiation with concurrent capecitabine, oxaliplatin, and bevacizumab followed by surgery and postoperative 5-fluorouracil, leucovorin, oxaliplatin (FOLFOX), and bevacizumab in patients with locally advanced rectal cancer: ECOG 3204. Cancer 119(8): 1521-1527.

Lindahl P, Johansson BR, Leveen P, Betsholtz C (1997) Pericyte loss and microaneurysm formation in PDGF-B-deficient mice. Science 277(5323): 242-245.

Liu Y, Starr MD, Bulusu A, Pang H, Wong NS, Honeycutt W, Amara A, Hurwitz HI, Nixon AB (2013) Correlation of angiogenic biomarker signatures with clinical outcomes in metastatic colorectal cancer patients receiving capecitabine, oxaliplatin, and bevacizumab. Cancer Med 2(2): 234-242.

Loupakis F, Cremolini C, Fioravanti A, Orlandi P, Salvatore L, Masi G, Di DT, Canu B, Schirripa M, Frumento P, Di PA, Danesi R, Falcone A, Bocci G (2011) Pharmacodynamic and pharmacogenetic angiogenesis-related markers of first-line FOLFOXIRI plus bevacizumab schedule in metastatic colorectal cancer. Br J Cancer 104(8): 1262-1269.

Loupakis F, Falcone A, Masi G, Fioravanti A, Kerbel RS, Del TM, Bocci G (2007) Vascular endothelial growth factor levels in immunodepleted plasma of cancer patients as a possible pharmacodynamic marker for bevacizumab activity. J Clin Oncol 25(13): 1816-1818.

Loven D, Be'ery E, Yerushalmi R, Koren C, Sulkes A, Lavi I, Shaked Y, Fenig E (2008) Daily low-dose/continuous capecitabine combined with neoadjuvant irradiation reduces VEGF and PDGF-BB levels in rectal carcinoma patients. Acta Oncol 47(1): 104-109.

Nogue M, Salud A, Vicente P, Arrivi A, Roca JM, Losa F, Ponce J, Safont MJ, Guasch I, Moreno I, Ruiz A, Pericay C (2011) Addition of bevacizumab to XELOX induction therapy plus concomitant capecitabine-based chemoradiotherapy in magnetic resonance imaging-defined poorprognosis locally advanced rectal cancer: the AVACROSS study. Oncologist 16(5): 614-620.

Resch G, De VA, Ofner D, Eisterer W, Rabl H, Jagoditsch M, Gnant M, Thaler J (2012) Preoperative treatment with capecitabine, bevacizumab and radiotherapy for primary locally advanced rectal cancer - a two stage phase II clinical trial. Radiother Oncol 102(1): 10-13.

Rodel C, Liersch T, Becker H, Fietkau R, Hohenberger W, Hothorn T, Graeven U, Arnold D, Lang-Welzenbach M, Raab HR, Sulberg H, Wittekind C, Potapov S, Staib L, Hess C, Weigang-Kohler K, Grabenbauer GG, Hoffmanns H, Lindemann F, Schlenska-Lange A, Folprecht G, Sauer R (2012) Preoperative chemoradiotherapy and postoperative chemotherapy with fluorouracil and oxaliplatin versus fluorouracil alone in locally advanced rectal cancer: initial results of the German CAO/ARO/AIO-04 randomised phase 3 trial. Lancet Oncol 13(7): 679-687.

Roh MS, Yothers GA, O'Connell MJ, Beart W, Pitot HC, Shields AF, Parda DS, Sharif S, Allegra CJ, Petrelli NJ, Landry JC, Ryan DP, Arora TL,
Evans TL, Soori GS, Chu RV, Landes RV, Mohiuddin M, Lopa S, Wolmark N (2011) The impact of capecitabine and oxaliplatin in the preoperative multimodality treatment in patients with carcinoma of the rectum: NSABP R-04. J Clin Oncol 29(suppl 15): abstract 3503.

Sathornsumetee S, Cao Y, Marcello JE, Herndon JE, McLendon RE, Desjardins A, Friedman HS, Dewhirst MW, Vredenburgh JJ, Rich JN (2008) Tumor angiogenic and hypoxic profiles predict radiographic response and survival in malignant astrocytoma patients treated with bevacizumab and irinotecan. J Clin Oncol 26(2): 271-278.

Selvakumaran M, Yao KS, Feldman MD, O’Dwyer PJ (2008) Antitumor effect of the angiogenesis inhibitor bevacizumab is dependent on susceptibility of tumors to hypoxia-induced apoptosis. Biochem Pharmacol 75(3): 627-638.

Shaheen RM, Tseng WW, Davis DW, Liu W, Reinmuth N, Vellagas R, Wieczorek AA, Ogura Y, McConkey DJ, Drazan KE, Bucana CD, McMahon G, Ellis LM (2001) Tyrosine kinase inhibition of multiple angiogenic growth factor receptors improves survival in mice bearing colon cancer liver metastases by inhibition of endothelial cell survival mechanisms. Cancer Res 61(4): 1464-1468.

Shin SJ, Jung M, Jeung HC, Kim HR, Rha SY, Roh JK, Chung HC, Ahn JB (2012) A phase I pharmacokinetic study of TSU-68 (a multiple tyrosine kinase inhibitor of VEGFR-2, FGF and PDFG) in combination with S-1 and oxaliplatin in metastatic colorectal cancer patients previously treated with chemotherapy. Invest New Drugs 30(4): 1501-1510.

Sitohy B, Nagy JA, Jaminet SC, Dvorak HF (2011) Tumor-surrogate blood vessel subtypes exhibit differential susceptibility to anti-VEGF therapy. Cancer Res 71(22): 7021-7028.

Smyth GK (2004) Linear models and empirical bayes methods for assessing differential expression in microarray experiments. Stat Appl Genet Mol Biol 3: Article3.

Sohn WJ, Lee JW, Park DG (2010) Change in expression of survivin caused by using oxaliplatin in HCT116 colon cancer cells. J Korean Soc Coloproctol 26(4): 246-253.

Spigel DR, Bendell JC, McCleod M, Shipley DL, Arrowsmith E, Barnes EK, Infante JR, Burris III HA, Greco FA, Hainsworth JD (2012) Phase II study of bevacizumab and chemoradiation in the preoperative or adjuvant treatment of patients with stage II/III rectal cancer. Clin Colorectal Cancer 11(1): 45-52.

Tong RT, Boucher Y, Kozin SV, Winkler F, Hicklin DJ, Jain RK (2004) Vascular normalization by vascular endothelial growth factor receptor 2 blockade induces a pressure gradient across the vasculature and improves drug penetration in tumors. Cancer Res 64(11): 3731-3736.

Verstraete M, Debucquoy A, Devos E, Sagaert X, Penninckx F, Begg A, Haustermans K (2013) Investigation of possible endogenous hypoxia markers in colorectal cancer. Int J Radiat Biol 89(1): 9-15.

Verstraete M, Debucquoy A, Sagaert X, Van Cutsem E, Haustermans K (2012) Anti-angiogenic therapy combined with chemoradiotherapy for patients with localized advanced rectal cancer. Adv Cancer Res Treatment 2012(796042): 1-30.

Voland C, Bord A, Peleraux A, Penarier G, Carriere D, Galiegue S, Cvitkovic E, Jbilo O, Casellas P (2006) Repression of cell cycle-related proteins by oxaliplatin but not cisplatin in human colon cancer cells. Mol Cancer Ther 5(9): 2149-2157.

Watanabe T, Kobunai T, Yamamoto Y, Matsuda K, Ishihara S, Nozawa K, Iinuma H, Ikeuchi H (2011) Gene expression of vascular endothelial growth factor A, thymidylate synthase, and tissue inhibitor of metalloproteinase 3 in prediction of response to bevacizumab treatment in colorectal cancer patients. Dis Colon Rectum 54(8): 1026-1035.

Weisshardt P, Trarbach T, Durig J, Paul A, Reis H, Tilki D, Miroschnik I, Ergun S, Klein D (2012) Tumor vessel stabilization and remodeling by anti-angiogenic therapy with bevacizumab. Histochem Cell Biol 137(3): 391-401.

Wildiers H, Guetens G, De BG, Verbeken E, Landuyt B, Landuyt W, de Bruijn EA, van Oosterom AT (2003) Effect of antivascular endothelial growth factor treatment on the intratumoral uptake of CPT-11. Br J Cancer 88(12): 1979-1986.

Willett CG, Boucher Y, di TE, Duda DG, Munn LL, Tong RT, Chung DC, Sahani DV, Kalva SP, Kozin SV, Mino M, Cohen KS, Scadden DT, Hartford AC, Fischman AJ, Clark JW, Ryan DP, Zhu AX, Blaszkowsky LS, Chen HX, Shellito PC, Lauwers GY, Jain RK (2004) Direct evidence that the VEGF-specific antibody bevacizumab has antivascular effects in human rectal cancer. Nat Med 10(2): 145-147. 
Willett CG, Boucher Y, Duda DG, di TE, Munn LL, Tong RT, Kozin SV, Petit L, Jain RK, Chung DC, Sahani DV, Kalva SP, Cohen KS, Scadden DT, Fischman AJ, Clark JW, Ryan DP, Zhu AX, Blaszkowsky LS, Shellito PC, Mino-Kenudson M, Lauwers GY (2005) Surrogate markers for antiangiogenic therapy and dose-limiting toxicities for bevacizumab with radiation and chemotherapy: continued experience of a phase I trial in rectal cancer patients. J Clin Oncol 23(31): 8136-8139.

Willett CG, Duda DG, Ancukiewicz M, Shah M, Czito BG, Bentley R, Poleski M, Fujita H, Lauwers GY, Carroll M, Tyler D, Mantyh C, Shellito P, Chung DC, Clark JW, Jain RK (2010) A safety and survival analysis of neoadjuvant bevacizumab with standard chemoradiation in a phase I/II study compared with standard chemoradiation in locally advanced rectal cancer. Oncologist 15(8): 845-851.

Willett CG, Duda DG, di TE, Boucher Y, Ancukiewicz M, Sahani DV, Lahdenranta J, Chung DC, Fischman AJ, Lauwers GY, Shellito P, Czito BG, Wong TZ, Paulson E, Poleski M, Vujaskovic Z, Bentley R, Chen HX, Clark JW, Jain RK (2009) Efficacy, safety, and biomarkers of neoadjuvant bevacizumab, radiation therapy, and fluorouracil in rectal cancer: a multidisciplinary phase II study. J Clin Oncol 27(18): 3020-3026.

Wilson PM, Yang D, Azuma M, Shi MM, Danenberg KD, Lebwohl D, Sherrod A, Ladner RD, Zhang W, Danenberg PV, Trarbach T, Folprecht G, Meinhardt G, Lenz HJ (2012) Intratumoral expression profiling of genes involved in angiogenesis in colorectal cancer patients treated with chemotherapy plus the VEGFR inhibitor PTK787/ZK 222584 (vatalanib). Pharmacogenomics J 13(5): 410-416.

Winkler F, Kozin SV, Tong RT, Chae SS, Booth MF, Garkavtsev I, Xu L, Hicklin DJ, Fukumura D, di TE, Munn LL, Jain RK (2004) Kinetics of vascular normalization by VEGFR2 blockade governs brain tumor response to radiation: role of oxygenation, angiopoietin-1, and matrix metalloproteinases. Cancer Cell 6(6): 553-563.

Yang SX, Steinberg SM, Nguyen D, Wu TD, Modrusan Z, Swain SM (2008) Gene expression profile and angiogenic marker correlates with response to neoadjuvant bevacizumab followed by bevacizumab plus chemotherapy in breast cancer. Clin Cancer Res 14(18): 5893-5899.

Zheng S, Han MY, Xiao ZX, Peng JP, Dong Q (2003) Clinical significance of vascular endothelial growth factor expression and neovascularization in colorectal carcinoma. World J Gastroenterol 9(6): 1227-1230.

This work is published under the standard license to publish agreement. After 12 months the work will become freely available and the license terms will switch to a Creative Commons AttributionNonCommercial-Share Alike 4.0 Unported License.

Supplementary Information accompanies this paper on British Journal of Cancer website (http://www.nature.com/bjc) 